\title{
Grey Crowned Crane and Shoebills Conservation Status and Linkage to Livelihoods of Lake Victoria Shores Adjacent Communities in Mayuge District, Eastern Uganda
}

\author{
Priscilla Nyadoi ${ }^{*}$, Laster Stoney Ogola ${ }^{1}$, Harriet Kyakyo ${ }^{1}$, Gilbert Tayebwa ${ }^{1}$, \\ John Bosco Lamoris Okullo1,2, Thomas Aramu3 \\ ${ }^{1}$ Uganda Wildlife Society, Kampala, Uganda \\ ${ }^{2}$ Makerere University, Kampala, Uganda \\ ${ }^{3}$ Department of Natural Resources and Environment, Mayuge District Local Government, Mayuge, Uganda \\ Email: `msnyadoi@yahoo.com, lastogola@gmail.com, hkyakyo@yahoo.com, Gilbert.tayebwa@gmail.com, \\ jblokullo@gamial.com, aramthomas@gmail.com
}

How to cite this paper: Nyadoi, P., Ogola, L. S., Kyakyo, H., Tayebwa, G., Okullo, J. B. L., \& Aramu, T. (2020). Grey Crowned Crane and Shoebills Conservation Status and Linkage to Livelihoods of Lake Victoria Shores Adjacent Communities in Mayuge District, Eastern Uganda. Journal of Geoscience and Environment Protection, 8, 175-191.

https://doi.org/10.4236/gep.2020.810013

Received: August 17, 2020

Accepted: October 19, 2020

Published: October 22, 2020

Copyright () 2020 by author(s) and Scientific Research Publishing Inc. This work is licensed under the Creative Commons Attribution International License (CC BY 4.0).

http://creativecommons.org/licenses/by/4.0/

(c) (i) Open Access

\begin{abstract}
This research was done among communities living adjacent to Lake Victoria Shores in Mayuge District to generate knowledge on Shoebill, Grey Crowned Crane conservation status and linkage to livelihoods. This knowledge was necessary to guide design and implementation of interventions that would deliver on the species conservation and adjacent communities' livelihood benefits at the same time. We obtained information through individual interviews with 101 members of households from targeted communities and key informers-technical officials from the district, and analysed this data using Statistical Package for the Social Sciences (SPSS) by Bryman and Cramer, (2011) Version 20. The results were then subjected to validation using focus group discussions with 10 groups of between $8-15$ individuals representing the targeted communities and other stakeholders and the results from this further validated with $\geq 250$ representatives of these stakeholders in a one day workshop and with evidences collected during field observations, before synthesis. The findings show: Grey Crowned Crane habitats declining due to mining, agriculture, fishing activities by adjacent communities for their livelihoods (food and income from sale of produce obtained from the species' habitats). The communities say they need to be engaged in development and implementation of integrated interventions that will improve their livelihoods while securing conservation for Grey Crowned Cranes. They among others
\end{abstract}


propose ecotourism enterprises, training and sensitization on environment and wildlife conservation practices, policies and laws to enhance their knowledge and compliance in management. The fisher folk say fish is often found within Grey Crowned Cranes' habitats and breeding grounds in the Lake and to avoid destroying the habitats, they need engine boats and standard fishing nets to enable fishing far away in the deeper waters. Crop farming communities say they need commercial, soil fertility improving tree species to plant boundary to the buffer zones so that they can prevent cultivation encroachment on Grey Crowned Crane habitats in the Lake Shores. The findings also reveal need for Grey Crowned Crane population structure studies, and, that of shoebill presence to determine management strategies for their survival in habitats.

\section{Keywords}

Populations, Habitats, Bird Species, Ordinance, GEF, International Union for Conservation of Nature, Crop Farmers, Fisher Folk

\section{Introduction}

Past studies internationally and, in Uganda have shown Grey Crowned Cranes habitats are declining (Olupot, 2014, 2016; International Union for Conservation of Nature (IUCN), 2017). Of relevance to this study's objectives and, Mayuge District Development aspirations, Mayuge prioritized six areas of investment towards its 2040 vision-“A prosperous Mayuge District with well-developed socio-economic infrastructure with people enjoying a high standard of living by 2040". These included, agriculture, tourism, natural resources and environment, feeder and community access roads, human capital development and, delivery of social services in health, education, community development, water and sanitation (Mayuge District Local Government, 2015).

To guide investments in the natural resources and environment sector in a sustainable manner, in Mayuge District, in 2012, the district enacted and adopted a natural resource management ordinance, 2012 (Mayuge District Local Government, 2012). This ordinance was in part enacted to help address problems of natural resources degradation that was high in the district. It aimed to promote restoration of habitats and conservation of wildlife species facing population depletion threats as, the district had lost over $95 \%$ of its natural resources (wetlands, forests and lakeshores buffer zones and associated wildlife populations) to human activities reportedly agriculture, settlements, lumbering, sand mining and others.

Grey Crowned Cranes, Shoebills, Waterbucks, were some of the species most affected by habitats/breeding ground loss and degradation in Mayuge District. These species are also among Uganda's most threatened wildlife with rapidly declining habitats (WCS, 2016). Specific objective of generating knowledge on conservation status of Grey Crowned Cranes and Shoebills in Mayuge district 
and the linkage this had to livelihoods of the communities living adjacent to its Lake Victoria Shores habitats was therefore pursued in this study. This knowledge was needed for identification and design of interventions that would help secure restoration of the species habitats and livelihoods of its habitat adjacent communities.

The questions we used to generate the data needed for our study were as follows: What do you think are the current population and habitats trend for the Grey Crowned Cranes and Shoebills in their habitats within your area in Mayuge District? What do you think have lead to the population and habitats trend you have described for Grey Crowned Cranes and Shoebills within your area in Mayuge District? How have the population and habitat trend for Grey Crowned Cranes and Shoebills in your area in Mayuge District you described above affected your means of obtaining income, food, health and culture (livelihoods) for your household? What do you think needs to be done to address problems if any with population and habitat trends for Grey Crowned Cranes within your area in Mayuge District and to address problems if any that the trends have caused on your means of obtaining income, food, health and culture needs for your household? Where in your area have you seen or do you usually see Shoebills?

\section{Background}

Countrywide, studies have shown that Uganda's biodiversity and in particular populations and habitats of species that are also internationally threatened continue to decline (WCS, 2016). The same has been reported from specific studies on Grey Crowned Cranes and Shoebills (Nachuha \& Musimami, 2015) in the Doho Wetland System and, Olupot (2014) at landscape level for Eastern Uganda. Although similar factors namely, agriculture, mining, fishing etc. are reportedly causing the declines in for habitats and populations for example of the Grey Crowned Cranes in Uganda, a national level conservation strategy is not applicable for conservation at the local scale as, impacts of changes in these anthropogenic factors on species diversity differ at that level (Nyadoi et al., 2014). Area specific studies remain crucial when one wants to identify specific species' appropriate conservation strategies in given habitats. This was the rationale for our study of Grey Crowned Cranes conservation status in Mayuge. Shoebills like Grey Crowned Cranes in Uganda are facing population depletion threats, recent counts estimate their populations to be composed of only hundreds of individuals (BirdLife International, 2018). According to IUCN Species Specialists Specific group, the shoebills are sedentary (Birdlife International, 2018) and this means sighting in an area would suggest a habitat. In Uganda, the Shoebill habitats range include, Lakes Victoria, Albert, Kyoga, River Nile and National Parks including Queen Elizabeth, Mburo and Murchison Falls National Park (WCS, 2016). No study exists however on, specific habitats or niches of the Shoebills within these various locations given for the species habitat range. Our exploration for the specie presence in Mayuge, one of the districts of the Lake Victoria 
shores which is one of the given ranges if therefore worthwhile and has provided additional knowledge to guide research on the species populations and habitats in Uganda as will be found later in the results and subsequent discussion in the later sections of this study.

To tackle decline problems with its wildlife species that are recognized to be facing threats even at international levels (such as Grey Crowned Cranes) Uganda is putting in place some conservation initiatives. The state of Environment Report 2017 gives some highlights on threats to species and habitats (NEMA, 2016, 2017), recently enacted Wildlife and Environment Acts (UWA, 2019; NEA, 2019) also give guidelines promoting conservation of such species and their habitats. Uganda Biodiversity Management Strategy and Action plan (NEMA, 2016) does the same and for Grey Crowned Cranes, a National Strategy for conservation exists. And in the support of these advances, our study has provided knowledge to guide specific habitats conservation initiatives for the needy Grey Crowned Cranes and Shoebills.

Of methodological importance, several approaches have been used to study bird species; Nachucha and Musimami counted, conducted individual interviews with communities and made field observation in the Doho wetlands to establish status of Grey Crowned Cranes in the habitat (Nachuha \& Musimami, 2015), She and others used bird counts and field observations for three years, to report on Grey Crowned Cranes in urban habitats (Nachuha et al., 2015) while at landscape study level, Olupot (Olupot, 2014) carried out field observations and interviews with communities and expects. In other studies focusing on methodologies for diversity studies in birds, Dranzoa and Pomeroy noted that time based bird species count had some advantages over transect counts when time and resources are limiting and that, a mixture of methods yield better results in diversity studies (Pomeroy \& Dranzoa, 2003; Dranzoa et al., 2011). Summarily all the above literature in methodology for bird studies allude to the fact that choice of methodology depends more on objectives sought in a given study though there many methods available for use. For our study, we used the methodology similar to those which were employed by Olupot, for his study for the same species at landscape level in Eastern (Olupot, 2014, 2016) but with customization as described in detail in our methodology section following.

\section{Methodology}

This study was done in Mayuge District located in Eastern Uganda on coordinates; $00^{\circ} 20^{\prime} \mathrm{N}, 33^{\circ} 30^{\prime} \mathrm{E}$, longitude $33^{\circ} 10^{\prime} \mathrm{E}, 34^{\circ} 0^{\prime} \mathrm{E}$ and at latitudes $0^{\circ} 06^{\prime} \mathrm{N}$, $1^{\circ} 12^{\prime} \mathrm{N}$. Total area of the district is $4678.22 \mathrm{~km}^{2}$ of which $76.62 \%\left(3584.66 \mathrm{~km}^{2}\right)$ is water and $23.38 \%\left(1093.56 \mathrm{~km}^{2}\right)$ land (Mayuge District Local Government, 2015). The villages where this study was conducted based on prior technical advice from the District technical officials (experts from the department of natural resources and environment) included, Ntinkalu (Wairasa), Musoli (Baitagombwe), Busalamu, Kakira (Malongo Subcounty), Namgera, Bukaboli (Kigan- 
dalo sub county), Ntonkolo, Buluuba, Katonte (Baitagombwe sub-county), Bute (Baitagombwe), Bugodi, Nalwesambula, Wainha, Bulanga, Walumbe, Nakalanga, Namugongo, Bukasero, Lwanika (Immanyiro sub-county), Bubalagala, Buwolomera, Kapaluko, Waigala, Bukaleba (Immanyiro sub-county), Bwondha, Bwembe, Namungoma, Kafu, Kitumbezi, Musubi, Bugoto (Kigandalo sub-county), Buyugu, Nabyama, Kirongo, Namavundu, Butubula, Sagiti Island, Masaka, Bukenye, Nkombe (Immanyiro sub-county), Kitovu (Kityeerera Subcounty) among others (Figure 1).

Data collection from key informants

For expert knowledge for this study, experts from the Natural Resources Department, with knowledge and experience on conservation issues and management of the targeted species and their habitats were involved as key informants who gave their knowledge on conservation status and habitats and, habitat adjacent communities who needed to be engaged in the study by virtue of the impacts of their activities on the species. For data collection based on individual interviews for habitat adjacent communities, we decided to involve local communities in identification of the targeted species and their habitats conservation needs and the linkage this had to their livelihoods rather conduct point count surveys. This decision was informed by literature from related past study on the species that revealed that more success in finding Grey Crowned Cranes in their habitats was obtained from community interviews rather than field observation/species counts in the field (Olupot, 2016). Therefore the current study based on local community perceptions to get information on the targeted species rather than field based sampling. This approach was also adopted to address time and other resource limitations, in addition to the stated reliability.

In Data collection, the first household from which the first respondent from whom data was collected for this study was selected at random, the next respondents were taken systematically from consecutive households and where persons found in at home at the time of visit refused to participate in the interview, the next household were taken. The households were approximately 30 - 50 metres apart (clustered) and five villages out of the seven along the Lake Victoria Shores and South Busoga Forest Reserve were covered in the study. The villages selected were, where, according to the expert knowledge, the targeted species are found and where their conservation needs and threats were high. Within each of the selected villages, a total of 12 to a maximum of 30 respondents were sampled and interviewed. The total number of respondents sampled per village dependent on availability of adult members of household at home at the time of visit for research and the available members' willingness to participate in the study. A questionnaire was predesigned and used to capture information answering the following questions; What the respondent thought were current population and habitats trend for the Grey Crowned Cranes and Shoebills in their habitats, What lead to the stated population and habitats trend for the species and their habitats, How the trends have or do affect means of obtaining income, food, 




Figure 1. Map of Mayuge District showing areas where the study was conducted and, location of Mayuge District in Uganda.

health and culture (livelihoods) for household of the respondent, what the respondent deemed needed to be done to address problems if any with population and habitat trends they stated and to resolve the effects in any the trends have caused on the respondents' household means of obtaining income, food, health, culture. The respondents were also asked where in their area they could have seen or usually see Shoebills?

Data for these questions were collected from a total of 101 respondents sampled following the procedure described before here, from the targeted communities living adjacent to the Lake Victoria Shores and South Busoga Forest Reserve habitats in Mayuge District. The data obtained from were analyzed using the Statistical package for the Social Sciences (SPSS) by (Byram and Cramer, Version 20, released in 2011 by IBM Corp.). In the package, percentages were generated on perceptions of the habitat adjacent communities, on Grey Crowned Crane and Shoebills populations and habitat status and the linkage this had to their livelihoods and, what interventions were required for conservation as well as livelihoods improvement. Results obtained from individual interviews were 
subjected to appraisal in focus group discussions involving 8 - 15 individuals; representatives of the communities from where the individual interviews were conducted and in total 80 were engaged. The results obtained after the focus group discussions were then validated in a one day workshop with more than 250 individuals that included representatives of the communities earlier engaged in the study and other stakeholders in the district including private sector, local government, civil society, religious organizations, conservation agencies and others in the district.

Additionally, this study involved field visits for observations to capture field evidences on the Grey Crowned Cranes habitats and populations status and indicators if any at field level of linkage between this and the adjacent communities' livelihoods. For example cultivations, fishing, mining activities in the species habitats and breeding ground and, the species presence in the habitats observable at the time of data collection was documented. These results were then all considered together in synthesis for the results and knowledge generated in this study.

\section{Results}

According to the analysis of the local expert from Mayuge district, Shoebills have been sighted in Mayuge District in the past but had not been sighted yet in 2019 and during the period of the study (Table 1). In his opinion the Shoebills may have died while, Grey crowned cranes populations are except in habitats under strict nature reserve and conservation initiatives Uganda Wildlife Authority and National Forestry Authority (Walumbe, Nakalanga and Namugoma), National Forestry Authority and the Mayuge District Local Government Department of Natural Resources (Lwanika, Buaksero, Buwolomera, Kapaluko, Bute, Waigala and Bukaleba CFR), Mayuge District Natural Resources Department (Bukasero, Lwanika, Bubalagala) and Buluuba, Buluuba Hospital and Katonte. Outside these areas, the expert reported Grey Crowned Cranes are generally found along the Lake Victoria shores in villages such as Masaka, Nkombe and Ntinkalu, wherein, no conservation efforts are ongoing and, habitats are being destroyed for sugar cane, rice, maize cultivation, fishing and sand mining among others human activities (Table 1 ). He proposed alternative livelihood options, sensitization and enforcement of policies and laws in addition to restoration activities in addition to engagement of sugar companies in the interventions, in order to achieve restoration of the species habitats.

The socioeconomic characteristics of respondents involved in individual interviews to obtain data for this study were as shown (Table 2). Overall, $81.20 \%$ of the 101 respondents were males and the rest were females. Also, 77.20\% of the respondents were married compared $22.80 \%$ who were still single. Majority $(59.40 \%)$ of the respondents were crop farmers, others were fisher folk, entrepreneurs and students (Table 2).

Overall, $63.40 \%$ and $31.70 \%$ of the 101 respondents involved in this study re- 
spectively perceived that Grey Crowned Crane and Shoebills populations and habitats in their local areas within Mayuge District were declining (Table 3).

Table 1. Expert opinion: Grey Crowned Cranes, Shoebills population/habitat status in Mayuge.

\begin{tabular}{|c|c|c|c|c|c|c|c|}
\hline Species & $\begin{array}{l}\text { Habitat/ } \\
\text { breeding areas }\end{array}$ & $\begin{array}{l}\text { Nature of } \\
\text { Vegetation }\end{array}$ & $\begin{array}{l}\text { Adjacent } \\
\text { Villages }\end{array}$ & Sub-county & $\begin{array}{l}\text { Status of } \\
\text { population }\end{array}$ & $\begin{array}{l}\text { Factors affecting } \\
\text { populations }\end{array}$ & $\begin{array}{l}\text { Conservation } \\
\text { interventions as } \\
\text { of } 2018\end{array}$ \\
\hline \multirow[t]{3}{*}{$\begin{array}{l}\text { Grey Crowned } \\
\text { Cranes }\end{array}$} & $\begin{array}{l}\text { Lake Shores, } \\
\text { Swamps Mash } \\
\text { lands }\end{array}$ & $\begin{array}{l}\text { Papyrus, Palms, } \\
\text { nut grass, } \\
\text { horsetails, } \\
\text { Phragmatit, } \\
\text { sedges, lilies }\end{array}$ & $\begin{array}{l}\text { Ntikanlu bay, } \\
\text { Busoli, Kakira, } \\
\text { Busalamu, }\end{array}$ & Wairasa & $\begin{array}{l}\text { Declining for } \\
\text { the last } 15 \\
\text { years }\end{array}$ & $\begin{array}{l}\text { Cultivation of } \\
\text { Sugar cane, Rice } \\
\text { Vegetation burning }\end{array}$ & None \\
\hline & & & $\begin{array}{l}\text { Ntokolo, Bukoli } \\
\text { and Namagera }\end{array}$ & Baitambogwe & Declined & $\begin{array}{l}\text { Sand mining } \\
\text { vegetation } \\
\text { clearance, } \\
\text { Ignorance of } \\
\text { laws inadequate } \\
\text { enforcement }\end{array}$ & $\begin{array}{l}\text { Limited sensitization } \\
\text { by the District. }\end{array}$ \\
\hline & & & $\begin{array}{l}\text { Buluba, Buluba } \\
\text { Hospital, Katonte } \\
\text { and Namagera }\end{array}$ & Baitambogwe & $\begin{array}{l}20 \text { birds } \\
\text { existing }\end{array}$ & $\begin{array}{l}\text { Being protected by } \\
\text { Buluba Hospital }\end{array}$ & $\begin{array}{l}\text { Being protected by } \\
\text { Buluba Hospital }\end{array}$ \\
\hline $\begin{array}{l}\text { Grey Crowned } \\
\text { Cranes and } \\
\text { Shoebills }\end{array}$ & & & $\begin{array}{l}\text { Walumbe, } \\
\text { Namugongo and } \\
\text { Nakalanga }\end{array}$ & Bukatube & $\begin{array}{l}\text { Population } \\
\text { increasing for } \\
\text { Grey } \\
\text { Crowned } \\
\text { Cranes. } \\
\text { Shoebills not } \\
\text { seen in recent } \\
\text { but sighted in } \\
\text { the past }\end{array}$ & $\begin{array}{l}\text { Strict Nature } \\
\text { reserve }\end{array}$ & $\begin{array}{l}\text { Game sanctuary } \\
\text { protected by } \\
\text { Environment Policy, } \\
\text { UWA, NFA }\end{array}$ \\
\hline Shoebill & & & $\begin{array}{l}\text { Bute, Bugodi, } \\
\text { Nalwesambu, } \\
\text { Wainha, Bulanga }\end{array}$ & Baitagombwe & $\begin{array}{l}\text { Sighted in } \\
\text { rainy seasons }\end{array}$ & $\begin{array}{l}\text { Vegetation } \\
\text { clearance, } \\
\text { ignorance of the } \\
\text { Law }\end{array}$ & None \\
\hline $\begin{array}{l}\text { Grey Crowned } \\
\text { Cranes and } \\
\text { Shoebills }\end{array}$ & & & $\begin{array}{l}\text { Bwonda, Bwembe, } \\
\text { Namungoma and } \\
\text { Kafu }\end{array}$ & Malongo & Declined & $\begin{array}{l}\text { Vegetation } \\
\text { clearance, } \\
\text { ignorance of } \\
\text { law inadequate } \\
\text { enforcement }\end{array}$ & None \\
\hline $\begin{array}{l}\text { Grey Crowned } \\
\text { Cranes and } \\
\text { Shoebills }\end{array}$ & & & $\begin{array}{l}\text { Kitumbezii, } \\
\text { Musubi, Bogoto, } \\
\text { Buyugu, } \\
\text { Nabyama } \\
\text { Kirongo, } \\
\text { Namayundu, } \\
\text { Butumbula }\end{array}$ & Bukabooli & Declining & $\begin{array}{l}\text { Vegetation } \\
\text { clearance, } \\
\text { ignorance of law, } \\
\text { inadequate } \\
\text { enforcement }\end{array}$ & None \\
\hline $\begin{array}{l}\text { Grey Crowned } \\
\text { Cranes, Shoebills }\end{array}$ & & & Jagusi Island & Jagusi Island & Declining & $\begin{array}{l}\text { Vegetation } \\
\text { clearance, } \\
\text { ignorance of } \\
\text { law inadequate } \\
\text { enforcement }\end{array}$ & None \\
\hline
\end{tabular}


Table 2. Socioeconomic characteristics of communities-respondents who gave their' perception on Grey Crowned Cranes and Shoebills conservation status in Mayuge District $(\mathrm{N}=101)$.

\begin{tabular}{|c|c|c|c|}
\hline $\begin{array}{l}\text { Respondent socio- } \\
\text { economic variable }\end{array}$ & Respondent particular & Frequency & Percentage (\%) \\
\hline \multirow[t]{2}{*}{ Sub-county } & Bukatube & 34 & 33.70 \\
\hline & Imanyiro & 67 & 66.30 \\
\hline \multirow[t]{2}{*}{ Parish } & Mbirabira & 34 & 33.70 \\
\hline & Nkombe & 67 & 66.30 \\
\hline \multirow[t]{5}{*}{ Village } & Buwerere & 20 & 19.80 \\
\hline & Masaka & 14 & 13.90 \\
\hline & Nakabale & 39 & 38.60 \\
\hline & Nkombe A & 15 & 14.90 \\
\hline & Nkombe B & 13 & 12.90 \\
\hline \multirow[t]{2}{*}{ Sex } & Male & 82 & 81.20 \\
\hline & Female & 19 & 18.80 \\
\hline \multirow[t]{3}{*}{ Age } & $18-35$ years & 53 & 52.50 \\
\hline & $36-50$ years & 30 & 29.70 \\
\hline & Above 50 years & 18 & 17.80 \\
\hline \multirow[t]{2}{*}{ Marital Status } & Single & 23 & 22.80 \\
\hline & Married & 78 & 77.20 \\
\hline \multirow[t]{4}{*}{ Household size } & Less than 3 members & 34 & 33.70 \\
\hline & 3 - 6 members & 28 & 27.70 \\
\hline & 7 - 10 members & 24 & 23.80 \\
\hline & More than 10 members & 15 & 14.90 \\
\hline \multirow[t]{3}{*}{ Education status } & No formal education & 4 & 4.00 \\
\hline & Primary & 34 & 33.70 \\
\hline & Secondary & 63 & 62.40 \\
\hline \multirow[t]{5}{*}{ Occupation } & Crop farmer & 60 & 59.40 \\
\hline & Fisher folk & 4 & 4.00 \\
\hline & Entrepreneur & 7 & 6.90 \\
\hline & Student & 12 & 11.90 \\
\hline & Other (Mechanic, cyclist, teacher, politician) & 18 & 17.80 \\
\hline \multirow[t]{3}{*}{ Duration in village } & Under 10 years & 7 & 6.90 \\
\hline & $10-20$ years & 15 & 14.90 \\
\hline & Over 20 years & 79 & 78.20 \\
\hline \multirow[t]{2}{*}{ Land ownership } & Yes & 67 & 66.30 \\
\hline & No & 34 & 33.70 \\
\hline \multirow[t]{4}{*}{ Landholding size } & Less than 1 Acre & 10 & 9.90 \\
\hline & $1-6$ Acres & 41 & 40.60 \\
\hline & Above 6 Acres & 15 & 14.90 \\
\hline & Do not own land & 35 & 34.70 \\
\hline
\end{tabular}


Table 3. Communities' perception on Grey Crowned Cranes and Shoebills conservation status in Mayuge District $(\mathrm{N}=101)$.

\begin{tabular}{|c|c|c|c|}
\hline Targeted Species & Population trend & Frequency & Percentage (\%) \\
\hline \multirow[t]{4}{*}{ Grey Crowned Crane } & Declining & 64 & 63.40 \\
\hline & Constant & 14 & 13.90 \\
\hline & Rising & 19 & 18.80 \\
\hline & Not sure about the trend & 4 & 4.00 \\
\hline \multirow[t]{4}{*}{ Shoebills } & Declining & 32 & 31.70 \\
\hline & Constant & 8 & 7.90 \\
\hline & Rising & 7 & 6.90 \\
\hline & Not sure about the trend & 54 & 53.50 \\
\hline
\end{tabular}

Grey Crowned Cranes and Shoebills population and habitat declines were said to have been due to activities like agriculture, fishing, mining and hunting done by communities living adjacent to the species habitats and the activities were done for purposes of their livelihood benefits that included meeting income, food, health and cultural/spiritual needs (Table 4).

Results obtained after validation workshop with over 250 stakeholders from the district were more inline with the results at focus group and individual interview levels, showing for example that the stakeholders perceived Grey Crowned Cranes and Shoebills Populations and their habitats were declining and interventions including sensitization are needed for restoration (Table 5).

Based on livelihood needs, interventions required for Grey Crowned Cranes conservation as well as deliver livelihood benefits to its habitat adjacent communities were as shown (Table 6).

The field evidences captured in form of photographs have not been included in this results section but can be availed upon request. However the photographic evidences gathered during data collection from the field show presence of Grey Crowned Cranes and encroachments, with agriculture and fishing activities among others taking place in this species habitats in Mayuge District as, reported by the adjacent communities and the district based experts. However, we did not encounter individual of Shoebills in all the field visits during data collection, including in the game sanctuary where the technical expert indicated in the species was sighted in the past. This is also despite reports by the communities that, they have sighted and usually see Shoebills in rainy seasons in their villages including Nakalanga, Masaka, Bubinge, Nkombe, Bujubi, Bukabooli (Musisi), Malongo, Buluba hospital and in Nkombe B.

\section{Discussion}

This study was conducted in order to generate knowledge on conservation status of Grey Crowned Cranes, Shoebills and the linkage this had to livelihoods of communities living adjacent their habitats in Mayuge District. The study aimed to generate knowledge to guide development and implementation of appropriate 
conservation strategy for the species. Emerging, whereas local communities in Mayuge confirm sighting Shoebills in villages like Nakalanga (Peninsular), Masaka landing site, Bubinge, Nkombe, Bujubi landing site, Bukabooli (Musisi), Malongo along the Lake Victoria shores, Buluba hospital and in Nkombe B. Technical officials of the district mentioned sighting a pair of the species in the game sanctuary in the past but say no recent sightings have been made, It is therefore likely the Shoebills are in Mayuge district, given that Lake Victoria is one of its few habitat ranges known in Uganda, and the fact that the species is sedentary (WCS, 2016; BirdLife International, 2018).

Table 4. Communities' perceptions on causes of Grey Crowned Cranes and Shoebills population and habitats decline in Mayuge District $(\mathrm{N}=101)$.

\begin{tabular}{|c|c|c|c|}
\hline Targeted species & Perceived causes of declining populations & Frequency & Percentage (\%) \\
\hline \multirow[t]{5}{*}{ Grey Crowned } & Destruction of swamps (especially for rice, sugar cane and other crops) & 42 & 41.60 \\
\hline & Deforestation/cutting of big trees & 12 & 11.90 \\
\hline & Killing/hunting/disturbance & 10 & 9.90 \\
\hline & Migration for safer habitat and food & 2 & 2.00 \\
\hline & Not sure of the cause & 35 & 34.70 \\
\hline \multirow[t]{5}{*}{ Shoebills } & Destruction of swamps (especially for rice, sugar cane and other crops) & 19 & 18.80 \\
\hline & Deforestation/cutting of big trees & 7 & 6.90 \\
\hline & Killing/hunting/disturbance & 6 & 5.90 \\
\hline & Migration for safer habitat and food & 5 & 5.00 \\
\hline & Not sure of the cause & 64 & 63.40 \\
\hline
\end{tabular}

Table 5. Community perception on Grey Crowned Crane Populations, Habitats status, linkage to livelihoods and interventions required for conservation of the species in Mayuge District.

\begin{tabular}{|c|c|c|c|}
\hline $\begin{array}{l}\text { Communities' } \\
\text { perception on } \\
\text { Grey Crowned } \\
\text { Cranes and } \\
\text { habitats status }\end{array}$ & $\begin{array}{l}\text { Communities perceived } \\
\text { livelihoods (income, food, health } \\
\text { and culture) benefits of declines in } \\
\text { Grey Crowned Cranes populations } \\
\text { and habitats }\end{array}$ & $\begin{array}{l}\text { Communities perceived negative impacts on } \\
\text { livelihoods (income, food, health and culture) of } \\
\text { declines in populations and habitats of Grey } \\
\text { Crowned Cranes on livelihoods (income, food, } \\
\text { health, culture) }\end{array}$ & $\begin{array}{l}\text { Interventions communities } \\
\text { recommend for improving } \\
\text { Grey Crowned Cranes } \\
\text { conservation and livelihoods }\end{array}$ \\
\hline \multirow[t]{4}{*}{$\begin{array}{l}\text { Habitats and } \\
\text { populations of Grey } \\
\text { Crowned Cranes } \\
\text { Declining }\end{array}$} & $\begin{array}{l}\text { Encroachment in habitats (wetlands, } \\
\text { lake shores, forests) has promoted } \\
\text { income generating activities like } \\
\text { farming }\end{array}$ & $\begin{array}{l}\text { Loss of bird species and their habitat lead to decline } \\
\text { in tourism potential that also negatively affect } \\
\text { potential revenues }\end{array}$ & $\begin{array}{l}\text { Provide alternative sources of } \\
\text { livelihoods to farmers, fisher folk } \\
\text { e.g. financial incentives and seed } \\
\text { for agriculture }\end{array}$ \\
\hline & $\begin{array}{l}\text { Encroachment in habitats has } \\
\text { enabled expanded crop cultivation } \\
\text { hence increased access of food }\end{array}$ & $\begin{array}{l}\text { The low tourism in the area will sustain low } \\
\text { infrastructural development, making it difficult for } \\
\text { crop farmers to transport their food products to the } \\
\text { market for sale }\end{array}$ & $\begin{array}{l}\text { Clear demarcation of } \\
\text { wetlands/Lake Buffer zones and } \\
\text { the Grey Crowned Crane } \\
\text { Habitats }\end{array}$ \\
\hline & $\begin{array}{l}\text { Presence of Grey Crowned Cranes } \\
\text { and Shoebills indicate location for } \\
\text { fish capturing }\end{array}$ & $\begin{array}{l}\text { Decline in rainfall caused supernaturally by crane } \\
\text { dances reduces crop productivity }\end{array}$ & $\begin{array}{l}\text { Compensate communities and } \\
\text { they leave wetlands }\end{array}$ \\
\hline & $\begin{array}{l}\text { Grey Crown Cranes and Shoebills } \\
\text { do not eat our crops hence food is } \\
\text { always available }\end{array}$ & $\begin{array}{l}\text { If wetlands are destroyed, global climate change will } \\
\text { be exacerbated hence affecting crop growing }\end{array}$ & $\begin{array}{l}\text { Community sensitization, } \\
\text { trainings, exchange visits to } \\
\text { where Grey Crowned Cranes } \\
\text { Conservation has been enhanced, } \\
\text { for capacity building }\end{array}$ \\
\hline
\end{tabular}


Grey Crown Cranes and Shoebills droppings improve soil fertility
Wetland ecosystem services such as rainfall formation, soil nutrients will be reduced hence affecting soil fertility which also affects food production among crop farmers and cause food insecurity

Grey crown cranes and shoebills occupy areas that would be suitable for cultivation hence reducing food access

Decline in habitats will increase populations of vectors such as mosquitoes into communities

There are still some herbal medicine in the remaining wetlands but they are declining

Decline in species or their habitat will deprive the future generation of knowledge of our totems (birds)

The Grey Crowned Cranes move very early in the morning, inspire us regarding time management, their absence will affect our valuation of time management

There will be spiritual detachment after the species and habitats decline

The feathers of the bird species are of cultural significance to us

Uganda's national bird will become extinct
Promote collaborative management of the species and habitats between authorities and communities

Promote Grey crowned Crane Based tourism development

Prevention of encroachment in habitats

Control all activities within the wetlands that would be a potential threat to conservation

Develop the infrastructure and health services and hospitality in the District

Table 6. Lake Victoria Shore Adjacent communities' perception on interventions required for Grey Crowned Crane Habitats conservation and livelihoods enhancement in Mayuge District.

\begin{tabular}{|c|c|c|c|c|c|}
\hline $\begin{array}{l}\text { (Village in } \\
\text { Mayuge } \\
\text { District } \\
\text { where the } \\
\text { communities } \\
\text { live) }\end{array}$ & $\begin{array}{l}\text { Community } \\
\text { Habitat Resource } \\
\text { User Group }\end{array}$ & $\begin{array}{l}\text { Number of } \\
\text { members } \\
\text { under resource } \\
\text { user } \\
\text { group/commu } \\
\text { nity }\end{array}$ & $\begin{array}{l}\text { Resource user group } \\
\text { perceived required } \\
\text { interventions for Grey } \\
\text { Crowned Crane Habitat } \\
\text { Conservation }\end{array}$ & $\begin{array}{l}\text { How the suggested } \\
\text { interventions will enhance } \\
\text { the community resource } \\
\text { user groups' livelihoods }\end{array}$ & $\begin{array}{l}\text { How suggested interventions } \\
\text { will enhance resource user } \\
\text { groups' participation in Grey } \\
\text { Crowned Crane Conservation }\end{array}$ \\
\hline Masaka & $\begin{array}{l}\text { Masaka Fishing } \\
\text { Communities }\end{array}$ & 132 & $\begin{array}{l}\text { Engine Boats with their } \\
\text { engines and Fleets of } \\
\text { standard Fishing Nets }\end{array}$ & $\begin{array}{l}\text { Engine boats, standard } \\
\text { fishing nets will enable fisher } \\
\text { folk fish deeper in the lake, } \\
\text { catch better fish that will earn } \\
\text { them more income }\end{array}$ & $\begin{array}{l}\text { The fisher folk will not fish in } \\
\text { Grey Crowned Crane Lake Shore } \\
\text { Habitats and Breeding Grounds } \\
\text { anymore and this will enable } \\
\text { restoration }\end{array}$ \\
\hline \multirow[t]{2}{*}{ Nkombe } & \multirow[t]{2}{*}{$\begin{array}{l}\text { Nkombe Fishing } \\
\text { Community }\end{array}$} & \multirow[t]{2}{*}{50} & $\begin{array}{l}\text { Boat Engines, Nets, } \\
\text { Cages }\end{array}$ & $\begin{array}{l}\text { The Engine Boats and } \\
\text { standard fishing nets will } \\
\text { enable fisher folk go far } \\
\text { deeper in the lake and catch } \\
\text { better fish. this will give them } \\
\text { better income }\end{array}$ & $\begin{array}{l}\text { The fisher folk will not engage in } \\
\text { fishing activities in the Grey } \\
\text { Crowned Crane Lake Shore } \\
\text { Habitats and Breeding Grounds } \\
\text { anymore and this will enable } \\
\text { restoration }\end{array}$ \\
\hline & & & $\begin{array}{l}\text { Ecotourism- } \\
\text { revenue shared with } \\
\text { communities, } \\
\text { communities trained, } \\
\text { engaged in making crafts } \\
\text { for income }\end{array}$ & $\begin{array}{l}\text { Revenue shared from } \\
\text { Ecotourism and income from } \\
\text { selling craft materials will } \\
\text { enable communities' get } \\
\text { livelihoods needs }\end{array}$ & $\begin{array}{l}\text { Ecotourism revenue will enable } \\
\text { community live off Grey } \\
\text { Crowned Crane Habitats and this } \\
\text { will lead to restoration and } \\
\text { conservation }\end{array}$ \\
\hline
\end{tabular}




\begin{tabular}{|c|c|c|c|c|c|}
\hline Ntinkalu & $\begin{array}{l}\text { Musoli tukolere } \\
\text { ghalala } \\
\text { Association } \\
\text { (rice growers } \\
\text { association) }\end{array}$ & 70 & $\begin{array}{l}\text { Engine Boats with their } \\
\text { engines and Fleets of } \\
\text { standard Fishing Nets }\end{array}$ & $\begin{array}{l}\text { The Engine Boats and } \\
\text { standard fishing nets will } \\
\text { enable fisher folk go far } \\
\text { deeper in the lake and catch } \\
\text { better fish. this will give them } \\
\text { better income }\end{array}$ & $\begin{array}{l}\text { The fisher folk will not engage in } \\
\text { fishing activities in the Grey } \\
\text { Crowned Crane Lake Shore } \\
\text { Habitats and Breeding Grounds } \\
\text { anymore and this will enable } \\
\text { restoration }\end{array}$ \\
\hline $\begin{array}{l}\text { Buluba } \\
\text { Hospital }\end{array}$ & $\begin{array}{l}\text { Hospital with over } \\
100 \text { acres of land } \\
\text { adjacent to the } \\
\text { Lake Victoria } \\
\text { shores and } \\
\text { habitats to the } \\
\text { Grey Crowned } \\
\text { Cranes }\end{array}$ & $\begin{array}{l}\text { Hospital } \\
\text { community } \\
\text { composed of } \\
\text { members from } \\
\text { the } \\
\text { surrounding } \\
\text { community } \\
\text { numbering } \\
\text { over } 50\end{array}$ & $\begin{array}{l}\text { Trees for } \\
\text { Conservation and } \\
\text { restoration of fish } \\
\text { ponds }\end{array}$ & $\begin{array}{l}\text { Community will plant trees } \\
\text { adjacent to Lake Shores, } \\
\text { leaving Buffer Zone for Grey } \\
\text { Crowned Cranes. They will } \\
\text { benefit from selling trees, } \\
\text { grow crops under them, } \\
\text { leading to better } \\
\text { environment/ soil fertility }\end{array}$ & $\begin{array}{l}\text { Buffer zone protection to be done } \\
\text { by the trees planted by the } \\
\text { communities will help prevent } \\
\text { encroachment on Grey Crowned } \\
\text { Habitats and this will cause } \\
\text { restoration of the species' } \\
\text { populations and habitats }\end{array}$ \\
\hline $\begin{array}{l}\text { Jomo Ikata } \\
\text { Nkombe }\end{array}$ & $\begin{array}{l}\text { Individual } \\
\text { large-scale } \\
\text { sugarcane grower } \\
\text { with over } 300 \\
\text { acres land in } \\
\text { Nkombe }\end{array}$ & $\begin{array}{l}\text { lindividual } \\
\text { with over } 300 \\
\text { acres of land } \\
\text { adjacent to the } \\
\text { Lake Victoria } \\
\text { Shores }\end{array}$ & $\begin{array}{l}\text { Trees for conservation of } \\
\text { the habitats }\end{array}$ & $\begin{array}{l}\text { The land owner expects to get } \\
\text { commercial benefit from the } \\
\text { trees in future and that the } \\
\text { trees will enhance soil } \\
\text { fertility }\end{array}$ & $\begin{array}{l}\text { The trees planted adjacent to } \\
\text { the lake shores will prevent } \\
\text { encroachment in buffer zone and } \\
\text { therefore enable restoration of } \\
\text { Grey Crowned Crane Habitats, } \\
\text { Breeding grounds }\end{array}$ \\
\hline $\begin{array}{l}\text { Arise Africa } \\
\text { International }\end{array}$ & $\begin{array}{l}\text { An/NGO engaged } \\
\text { in Agroforestry } \\
\text { along the Lake } \\
\text { shores, orphanage } \\
\text { and a school in } \\
\text { Masaka }\end{array}$ & $\begin{array}{l}200 \text { members } \\
\text { in Buwere, } \\
\text { Masaka and } \\
\text { Mbirambira }\end{array}$ & $\begin{array}{l}\text { Agroforestry involving } \\
\text { fruit trees and Apiculture } \\
\text { with the lake adjacent } \\
\text { communities }\end{array}$ & $\begin{array}{l}\text { Apiculture, fruit trees will } \\
\text { provide income and divert } \\
\text { communities from cultivation } \\
\text { of crops in Lake Buffer zone } \\
\text { habitat of Grey Crowned } \\
\text { Cranes }\end{array}$ & $\begin{array}{l}\text { Apiculture and fruit tree growing } \\
\text { will lead to better farming } \\
\text { practice adjacent to the Lake } \\
\text { Shores and preserve Habitats of } \\
\text { Grey Crowned Cranes and this } \\
\text { will lead to conservation }\end{array}$ \\
\hline $\begin{array}{l}\text { Mayuge Sugar } \\
\text { Company }\end{array}$ & $\begin{array}{l}\text { Company for } \\
\text { whom the Sugar } \\
\text { Cane Out growers } \\
\text { supply sugar cane }\end{array}$ & $\begin{array}{l}\text { Company with } \\
4500 \text { out } \\
\text { grower farmers } \\
\text { adjacent to the } \\
\text { Lake Victoria, } \\
\text { in NKombe. } \\
\text { Kitovu, } \\
\text { Bukukenye } \\
\text { Masaka }\end{array}$ & $\begin{array}{l}\text { Ecotourism, seed, financial, } \\
\text { incentives, sensitization, } \\
\text { training in appropriate } \\
\text { practices, policies, laws } \\
\text { will reduce } \\
\text { encroachment, } \\
\text { community will } \\
\text { demarcate buffer zones } \\
\text { with trees }\end{array}$ & $\begin{array}{l}\text { Out growers sensitized will } \\
\text { not engage in destructive } \\
\text { cultivation of the Crane } \\
\text { Habitats and hence will lead } \\
\text { to conservation }\end{array}$ & $\begin{array}{l}\text { Continue sensitization, company } \\
\text { committed of farmers to } \\
\text { appropriate farming practices, } \\
\text { construct waste management } \\
\text { plant to reduce waste disposal in } \\
\text { the lake impacting negatively on } \\
\text { habitat of Grey Crowned Cranes, } \\
\text { will lead to restoration }\end{array}$ \\
\hline $\begin{array}{l}\text { Mayuge Sugar } \\
\text { Cane Out } \\
\text { growers } \\
\text { Association }\end{array}$ & $\begin{array}{l}\text { Masil Cane } \\
\text { Growers farmers } \\
\text { supplying sugar } \\
\text { cane to Mayuge } \\
\text { Sugar Industry and } \\
\text { growing their } \\
\text { sugar cane in } \\
\text { villages including; } \\
\text { in NKOMBE. } \\
\text { KITOVU, } \\
\text { BUKENYE, AND }\end{array}$ & $\begin{array}{l}4500 \text { individual } \\
\text { farmers in } \\
\text { Masaka }\end{array}$ & $\begin{array}{l}\text { Knowledge of law } \\
\text { requiring } 200 \mathrm{~m} \text { of lake } \\
\text { buffer zone protection } \\
\text { will make farmers stop } \\
\text { encroachment } \\
\text { restoration }\end{array}$ & $\begin{array}{l}\text { Sensitization, capacity } \\
\text { building trainings, } \\
\text { commitment to planting } \\
\text { indigenous grass to restore } \\
\text { Grey Crowned Crane } \\
\text { Habitats }\end{array}$ & $\begin{array}{l}\text { Sensitization, commitment of } \\
\text { farmers to appropriate farming } \\
\text { and waste management practices, } \\
\text { will reduce encroachment on } \\
\text { Buffer Zones and cause } \\
\text { restoration of Grey Crowned } \\
\text { Cranes Habitats. }\end{array}$ \\
\hline
\end{tabular}

Our findings on the presence of Shoebills in Mayuge District here is inconclusive as the communities and the district technical experts though both agree on sighting the species; the later refute its current presence in the district. Our study did not include detailed ecological observations for the species presence in the 
district, which would have helped generated detailed knowledge on population and habitat. We therefore recommend a long term 2 to 3 years' ecological observations to determine if Shoebills exist in Mayuge District. Ecological studies of such periods are able to help elucidate population dynamics. Nachuha and others for example were able to establish Grey Crowned Cranes breeding in modernized urban habitats though the species is known not to breed in captive or unnatural habitats (Nachuha et al., 2015). Unlike the Shoebills, Grey Crowned Cranes were seen in villages along the Lake Victoria Shores and Islands in Mayuge during this study and as reported by technical experts, habitat adjacent communities and supported by field observation evidences, the species habitats have been degraded by anthropogenic activities. These included sand mining, fishing, agriculture with crops such as rice, sugar cane, cassava and maize found growing and, settlements for the fisher folk within the Lake buffer zones.

To bring out Grey Crowned Crane Habitat linkage to their livelihoods, the adjacent communities acknowledged that they were aware that their activities were destructive to the species. Adding that, of negative impacts, they are aware their activities will causing habitat declines and among others this will cause, wetland ecosystem services reduction which will lead to food insecurity, increase in populations of vectors and associated diseases, depletion of herbal medicinal species, loss of knowledge, culture, spiritual and national heritage benefits from these habitats and the Grey Crowned Cranes. Additionally, in relation to their livelihoods, the communities perceive that declines in Grey Crowned Crane Populations and habitats will cause decline in tourism and tourism revenue and therefore perpetuate poor infrastructural development, which will continue to limit access to markets for their produce. They also perceive Grey Crowned Crane dances reduce rainfall and that the species occupy areas which would have been suitable for cultivation and therefore in a way limit livelihoods benefits.

Despite the perceived existing and potential negative impacts decline in populations and habitats of Grey Crowned Cranes will have in future, the communities reported that as sources of their livelihoods currently, they get income from sale of crops and fish they harvest from the species habitats. They also grow food crops and harvest herbal medicine and cultural resources from these habitats adding that, encroachment on them has enhanced their income as they have been able to expand their commercial and food crop cultivation in the wetlands. The fisher folk said Grey Crowned Cranes and their breeding ground location helps them know where fish is in the Lake, making it easy for them to capture. The communities appreciate that Grey Crowned Cranes do not destroy their crops and its droppings improve soil fertility thus making their farmlands productive.

Considering the above linkages between their livelihoods and Grey Crowned Crane populations and habitats status, the habitat adjacent communities acknowledge need for conservation and recommended integrated strategies that would deliver on this as well as on their livelihoods. In specific, fisher folk said 
they needed engine boats and standard fishing nets to help them fish far deeper in waters away from the species habitats/breeding grounds, acknowledging that this would cause restoration of the habitats while enhancing their income as they will catch more fish. Crop farmers on the other hand asked for soil fertility improving, commercial tree species that they can plant at the boundary with the Lake buffer zones, to prevent encroachment on the Grey Crowned Crane habitats. Additionally the communities said they needed training on conservation practices, policies, laws and engagement in tourism enterprises for livelihoods diversification while conserving habitats and populations of the Grey Crowned Cranes. This finding overall demonstrated willingness to engage in conservation of habitats and populations of Grey Crowned Cranes by adjacent communities provided stated incentives are given. The communities for example, welcome partnerships with local government and private sector in programmes for Grey Crowned Crane conservation and the species' based ecotourism enterprises. This finding support past studies that have called for livelihood incentives and partnerships in conservation (Olupot, 2016; Nyadoi et al., 2018) and as promoted for example by GEF Small grants programmes, Uganda's National Biodiversity Strategy and Action Plan (NEMA, 2016) and all the more recent country polices and laws such as the NEA (2019) and Uganda Wildlife Act (2019).

Whereas focus has been on Grey Crown Cranes, knowledge generated and presented in this study provide location specific guidelines for the species conservation and lessons for scaling up in similar areas elsewhere in Uganda. The knowledge will also be useful for international policies in relation to the Grey Crowned Cranes whose populations internationally are considered endangered. Nevertheless, this study based on presence and not detailed populations structure investigations for the species in Mayuge District, therefore estimation on number of individuals in the different age group for the species in the populations were not possible. We recommend long-term field population sampling to determine this as, such information will be helpful in identifying, designing and implementing management strategies for individuals' survival in the populations and habitats.

\section{Conclusion and Recommendation}

Findings of this study which were carried out in order to generate knowledge on Grey Crowned Cranes and Shoebills conservation status and the linkage this had to livelihoods of communities living adjacent to their habitats along the Lake Victoria Shores habitats show that Grey Crowned Crane habitats in Lake Victoria Shores Mayuge District are declining due to mining, agricultural and fishing activities for industry and livelihoods of communities living adjacent who say the habitats are sources of their livelihoods. To achieve conservation for Grey Crowned Cranes in Mayuge District, the communities recommend integrated strategies that also provide livelihood benefits to communities be implemented of which they proposed: Grey Crowned Cranes based ecotourism enterprises 
engaging them revenue sharing and income is generating activities like craft making. The communities want to be trained and sensitized on environment and wildlife conservation practices, policies and laws to enhance their knowledge and compliance. The fisher folk want engine boats and standard fishing nets to enable them to fish deeper in the Lake, far away from the Grey Crowned Crane Habitats and breeding grounds while, crop farmers want commercially beneficial-soil fertility enhancing tree species that they can plant in their farmlands adjacent to the Lake Shores along the boundary with buffer zones to protect the species habitats.

We did not conduct population structure study for Grey Crowned Cranes and did not have generated conclusive evidence on presence of Shoebills in Mayuge District but such information will be useful in determining management strategies for species individual survival in habitats. Therefore, we recommend detailed population structure and diversity studies on the Grey Crowned Cranes and Shoebills respectively in Mayuge District, to generate this information.

\section{Acknowledgements}

This research was made possible with financial support from Global Environment Facility (GEF), United Nations Development Programme (UNDP) and Government of Uganda (GoU), under the Small Grants Programme and from, Columbus Zoo and Aquarium. Respectively, we thank the National Coordinator Mr. Abubaker S. Wandera, Dr. John Stephen Okuta and, Jennifer Compston for their coordination and support in delivery of the funds that made this work possible. We thank members of the communities and all stakeholders in Mayuge District who made time to participate and give information we required in this study. We are grateful for the editorial and review inputs from the reviewer for the Journal of Geosciences and Environment Protection that has enabled us to improve our manuscript.

\section{Conflicts of Interest}

The authors declare no conflicts of interest regarding the publication of this paper.

\section{References}

BirdLife International (2018). Balaeniceps rex. The IUCN Red List of Threatened Species 2018: e.T22697583A133840708. https://doi.org/10.2305/IUCN.UK.2018-2.RLTS.T22697583A133840708.en

Bryman, A., \& Cramer, D. (2011). Statistical Package for the Social Scientists (SPSS) Version 20. Released in 2011, Armonk, NY: IBM Corp.

Dranzoa, C., Williams, C., \& Pomeroy, D. (2011). Birds of Isolated Small Forests in Uganda. Scopus, 31, 1-10.

IUCN (2017). The IUCN Red List of Threatened Species. Version 2017-3. http://www.iucnredlist.org

Mayuge District Local Government (2012). Management of Natural Resources Ordinance 
2012. Entebbe: Government of Uganda, UPPC.

Mayuge District Local Government (2015). Mayuge District Local Government District Development Plan ii 2015/2016-2019/2020. Mayuge District Local Government.

Nachuha, S., \& Musimami, P. (2015). The Current Populations and Threats Affecting the Grey Crowned Cranes Balearica regulorum in the Doho Wetlands, Eastern Uganda. https://www.africanbirdclub.org/sites/default/files/2015_Grey_crowned_Crane_Ugand a.pdf

Nachuha, S., Muheebwa-Muhooz, J., Ndibaisa, D., Kibuule, M., \& Pomeroy, D. (2015). Grey Crowned Cranes, Balearica regulorum in Urban Areas of Uganda. Scorpus, 34, 48-51.

National Environment Act (NEA) (2019). Government of Uganda, Enttebbe.

National Environment Management Authority (NEMA) (2016). National Biodiversity Strategy and Action Plan II (2015-2025) Theme: Supporting Transition to a Middle Income Status and Delivery of Sustainable Development Goals. Uganda: NEMA.

National Environment Management Authority (NEMA) (2017). State of the Environment Report 2016-2017. Kampala, Uganda: NEMA.

Nyadoi, P., Ogola, L. S., \& Aramu, T. (2018). Elucidating Conservation Needs of Grey Crowned Crane, Shoebill and Waterbucks in Mayuge District, Eastern Uganda. Uganda Wildlife Society and Mayuge District Local Government.

Nyadoi, P., Okori, P., Okullo, J. B. L., Obua, J., Fluch, S., Burg, K., \& Jamnadass, R. (2014). Tamarindus indica L. Patterns of Diversity from the Genetic to the Niche-Species Level in East Africa. Tropical Ecology Journal, 55, 19-32.

Olupot, W. (2014). Mapping Threats to Grey Crowned Crane in Eastern Uganda. https://endangeredwildlifetrust.wordpress.com/2014/09/24/mapping-threats-to-grey-cr owned-cranes-in-eastern-uganda-results-of-a-rapid-survey-for-conservation-action

Olupot, W. (2016). Grey Crowned Crane Threat Assessment around the Wetlands of Eastern Uganda. Ostrich, 87, 263-270. https://doi.org/10.2989/00306525.2016.1214931

Pomeroy, D., \& Dranzoa, C. (2003). Methods of Studying the Distribution, Diversity and Abundance of Birds in East Africa-Some Quantitative Approaches. African Journal of Ecology, 35, 110-123. https://doi.org/10.1111/j.1365-2028.1997.077-89077.x

Uganda Wildlife Act (UWA) (2019). Government of Uganda, Entebbe.

WCS (2016). Nationally Threatened Species for Uganda.

http://www.nationalredlist.org/files/2016/03/National-Redlist-for-Uganda 